\title{
Determinants of Foreign Direct Investment in Indonesia "Evidence from Co-Integration and Error Correction Modeling"
}

\author{
Alessandro Gabrielle Wijaya ${ }^{1}$, Dewi Astuti ${ }^{1}$, Zeplin Jiwa Husada Tarigan ${ }^{1 *}$, and \\ Natasya Edyanto ${ }^{2}$ \\ ${ }^{1}$ Faculty of Business and Economics, Petra Christian University. Jl. Siwalankerto 121-131, \\ Surabaya 60236, Indonesia \\ ${ }^{2}$ Chung Yuan Christian University, No. 200, Zhongbei Road, Zhongli District, \\ Taoyuan City, Taiwan 320
}

\begin{abstract}
This study aims to examine the influence of macroeconomic indicators and infrastructure spending on foreign direct investment (FDI) in the period 1981 to 2018. This study uses a quantitative approach. The sample in this study is macroeconomic variables, which include gross domestic product, inflation, debt to GDP ratio, interest rates, exchange rates, and infrastructure spending in the 1981 to 2018 period. The analysis technique used is cointegration and error correction modeling. The analysis shows that gross domestic product, inflation, debt to GDP ratio, interest rates, exchange rates, and infrastructure spending have a long-term and short-term relationship to FDI.
\end{abstract}

Keywords: Gross domestic product, infrastructure spending, inflation, interest rates macroeconomics.

\section{Introduction}

Foreign Direct Investment (FDI) is an international capital flow where foreign investors from one country invest their capital in another country. Usually, FDI is related to investment in productive assets by foreign investors. According to UNCTAD, FDI is defined as an investment that involves long-term relationships and reflects long-term interests and is controlled by a resident entity within an economy (foreign direct investors or holding companies) from companies residing in different economies. On the other hand, a Foreign Portfolio Investment (PFI) is the flow of capital to countries seeking financial benefits in the short and medium term through investments in the stock and bond markets. PFI is generally disliked by countries because it is associated with rapid outflows in times of crisis, which disrupts the stability of the local financial markets. In the last two decades, it has been a significant increase in FDI inflow throughout the world. As a developing country, Indonesia has several problems, one of which is the limited funding for economic development [1].

\footnotetext{
*Corresponding author: zeplin@peter.petra.ac.id
} 
Limited funding is a problem that often occurs in economic development. In the era of Jokowi's presidency, the current leader has carried out economic reforms, namely by issuing economic policy packages and eliminating fuel subsidies. The elimination of fuel subsidies brings an impact on the rating of Indonesia by Standard and Poor in May 2015, which previously was given a $\mathrm{BB}+$ stable outlook to a $\mathrm{BB}+$ positive outlook [2]. With the improvement of administrative policies in the era of Jokowi's presidency, Indonesia can create many foreign investment opportunities. This is in line with President Jokowi's dream of putting more emphasis on developing infrastructure for Indonesia, especially the eastern part of Indonesia, the sea toll project, and the construction of electricity and other infrastructure.

The problem that often occurs in developing countries is limited funds. Indonesia, as a developing country, needs large funds to carry out national development. One potential source of financing is FDI [3]. Thus, Indonesia can utilize FDI to conduct development in Indonesia. FDI is more important in ensuring sustainable development compared to the flow of aid (grants) or foreign portfolios because the occurrence of FDI in a country will be followed by the transfer of technology, know-how, management skills, business risk is relatively small and more profitable.

There are several factors that influence foreign direct investment that can help a country's economic development. Economic growth is one of the factors that influence FDI investment, long term positive influential impact between macro analysis of economic growth achieved by a country as measured by the balance of real national income achieved by that country [4]. A country's economy is said to increase if the number of goods and the number of services has increased so that a country's economic growth will increase domestic saving and investment so that it has a positive impact on FDI [1]. Inflation is an indicator to observe the level of change and is considered to occur if the price increase process continues and influences each other. This shows that inflation is an indicator of the level of stability of a country, but in terms of investors will see inflation as the level of risk of a country in the stability of a country. The higher level of inflation will result in a decrease in the amount of FDI entering a country

In addition to economic growth and inflation, investment costs in the form of cost of capital also determine investment interest from investors. The level of cost of capital can be seen through the interest rate on loans, which applies in a country as investment costs in the form of cost of capital. Interest rates are set in a country, the lower the interest rate, the lower the inflation. As a result, people's purchasing power rises, and investment interest increases [5].

The exchange rate is one of the factors in creating FDI flows in the host country. Besides, the exchange rate also acts as an indicator of the stability of the country, so that foreign investors can use the exchange rate indicator as one of the decisions in making decisions in investing. Debt to GDP ratio is the ratio of the level of risk or soundness of debt in a country that compares a country's debt to a country's total income. The factors influencing the entry of FDI are the debt to GDP ratio for short periods and long periods, there is a negative influence between the ratio of debt to GDP to a country's FDI [6].

The government of Indonesia hopes that investment interests outside Java can increase, but infrastructure limitations (roads, bridges, railroad tracks, etc.) are a separate problem in attracting foreign investment in developing infrastructure outside Java. Infrastructure development by the government is a factor that can attract foreign investors in investing. Because with the readiness of infrastructure in Indonesia, it can make investors easier to invest their funds in the infrastructure sector itself. If infrastructure, such as roads, ports, and railways for development needs is already available, it is certain that investments related to the sector will increase rapidly. Good infrastructure can significantly make 
overhead costs cheaper [7]. Empirical evidence shows that the availability of the required infrastructure in the host country positively influences FDI inflows [8].

\section{Related theory}

\subsection{Foreign direct investment (FDI)}

Referring to the provisions contained in the Investment Law No. 25, 2007, Foreign Direct Investment (FDI) is an investment activity to conduct business in the territory of the Republic of Indonesia, which is carried out by foreign investors, both those that use fully foreign capital and those who join domestic investors. Foreign investment, or commonly referred to as FDI, is also an effort to increase the amount of capital for economic development sourced from abroad [9]. The definition of FDI as contained in the balance of payments manual is an investment made to obtain a perpetual interest in companies operating outside the investor economy [10].

\subsection{Macroeconomics}

Macroeconomics is one branch of economics that focuses on economic behavior and policies that can affect the level of consumption, investment, trade balance, and balance of payments of a country. In summary, it can be said that macroeconomics is very concerned about the interaction between labor, the rotation of goods, and economic assets that result in trade activities of each individual or country [11]. Macroeconomics is the study of "total" or aggregate major economies. Macroeconomics is the study of world economic phenomena; for example, government regulations, unemployment rates, and economic growth [12].

\subsection{Interest rate parity (IRP)}

Interest rate parity (IRP) is a theory that the difference in interest rates between the two countries is the same as the difference between the forward exchange rate and the spot rate parity interest rate plays an important role in the foreign exchange market, linking interest rates, spot exchange rates, and foreign exchange rates. Conditions in which the market will adjust the interest rate with the exchange rate so that there is no possibility of arbitrage so that a balanced state occurs led the interest rate parity [13]. IRP is where an arbitration condition that always adjusts so that there is a level of balance in the international financial markets [14].

\subsection{Relationships between concepts}

\subsubsection{GDP to $F D I$}

Economic Growth has a strong role in describing a country's economy. If the economy is always growing, it will create investment interest in high-growth countries; but if the economic growth in a bad country indirectlfy reduces investor's confidence in the country. This is also supported by several previous studies. The long-term growth rate in a country will improve the economic situation in the country [15]. A good level of GDP growth will have a positive impact on the country because it will attract investors to invest [16]. However, there are studies that argue about the negative impact between GDP and FDI that results [17]. 


\subsubsection{External debt to GDP and FDI}

Debt is an indicator to show the level of risk. In investing in companies, there have been several ways to see risk, one of which is the DER ratio, but this study will use the debt to GDP ratio to see the risk of a country [18]. FDI can solve the problem of foreign debt accumulation in developing countries and also increase per capita income. Excessive dependence on foreign debt can be associated with enormous risk and can hamper the growth of developing countries [19]. The factors influencing foreign capital entry are from external debt to Gross Domestic Products for the short and long term, and have a negative impact between the ratio of debt to GDP to FDI.

\subsubsection{Inflation to FDI}

Inflation is a condition where prices generally increase continuously while, on the other hand, the level of income of the community is relatively fixed. The economic instability of a country can be a barrier to the entry of investment into a country. High inflation illustrates that the country's economy is unstable, which means the country's government has failed to balance the economy [20]. Inflation can cause a greater risk of business failure. The high level of inflation makes public consumption decrease because of the declining ability of people to buy goods due to soaring prices. Inflation is prolonged, many producers will go bankrupt because their products will be relatively more expensive so that no one can afford it. It can be concluded that there is a negative relationship between inflation and investment. That is, the more unstable the macroeconomy of a country, the lower the level of investment. The inflation is positively influencing the FDI due to the occurrence of a stimulus in the economy due to increased inflation and interest rates so as to provide a positive impact on FDI.

\subsubsection{Interest rates to FDI}

Interest rates are costs that must be paid by capital debtors for loans or the use of a sum of money to a capital lender. There is a negative influence between interest rates and investment levels. This means that if interest rates are high, the amount of investment will decrease. On the contrary, low interest rates will encourage more investment [21]. If interest rates rise, loans will become more expensive and cause fewer projects that investors can run. Conversely, if interest rates fall, borrowing costs are cheaper and will increase the number of projects that can be run by investors. Other studies also provide a positive impact between interest rates and FDI. Increase in interest rates has a positive relationship in the long run as the expected rate of return on investments made in the host country [22].

\subsubsection{USD exchange rate to FDI}

The exchange rate is the rate of a currency used by one country to another country. Exchange rates can be a driving factor for FDI flows in destination countries, because weakening the currency of the destination country (the host country) will increase investment returns for investors [4]. The exchange rate has a positive impact on FDI [17].

\subsubsection{Infrastructure expenditure to FDI}

Government readiness in providing infrastructure can also create attractions for investors to invest in. This can be measured by the level of government expenditure, which can show 
the level of government involvement in the economy. Government spending can attract FDI inflow [23]. FDI show that FDI in Africa depends on the level of infrastructure development [24].

\subsection{Research framework}

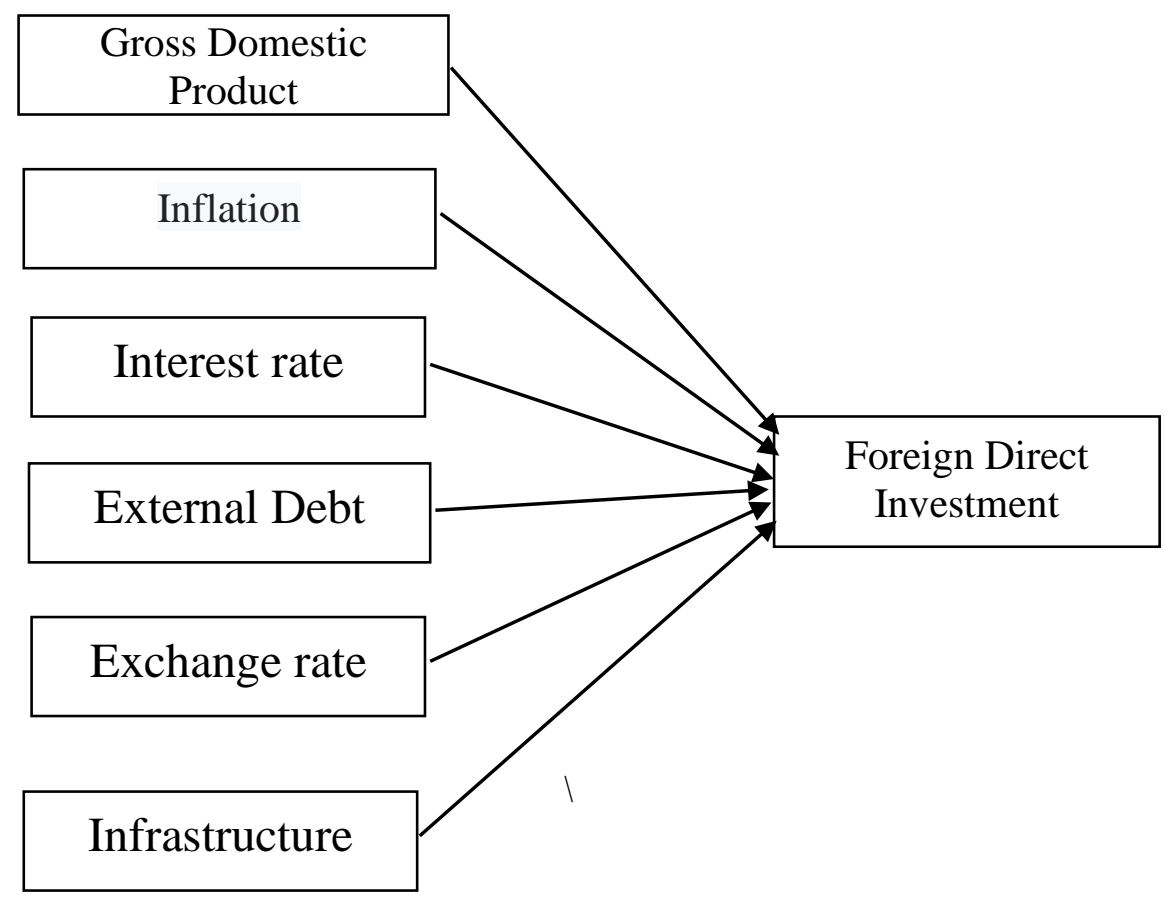

Fig. 2. Research framework

Based on the aim of this research and the impact between concepts, the hypothesis for this research are constructed as follows:

H1: GDP, rasio debt to GDP, inflation, interest rate, exchange rate, and government infrastructure expenditures have impacts on the long term FDI in Indonesia.

H2: GDP, rasio debt to GDP, inflation, interest rate, exchange rate, and government infrastructure expenditures have impacts on the short term FDI in Indonesia.

\section{Research method}

This research belongs to the quantitative research, and the variables used in this study are GDP, debt to GDP, inflation, interest rates, exchange rates, and infrastructure spending as the independent variables. While the dependent variable is FDI. In this study, the population to be examined is the annual data from FDI, economic growth, debt to GDP, inflation, interest rates, foreign exchange reserves, and infrastructure spending from the period 1981 to 2018 . The data source used in this study is secondary data that are data collected by agencies and published to the user or community. The source of the data is taken from the website of Bank Indonesia, the statistical center, the investment coordination agency, and the World Bank website. 
Stationary is a time series data condition which, if the mean, variance, and covariance of the variables are not all affected by time. Data testing can be done using the Augmented Dickey-Fuller (ADF) and Phillips-Peron (PP) tests. The data can be said as stationary data if there is a root unit in the data. The procedure to find out stationary data or not is by comparing the statistical value of ADF or PP with the critical value of the Mac Kinnon distribution. The ADF or PP statistical value is indicated by the t-statistic value. If the absolute value of the ADF or PP statistic is greater than the critical value, the observed data shows stationary, and if the ADF or PP statistical value is smaller than the critical value, then the data is not stationary.

Cointegration test can be used to determine whether two or more economic variables or financial variables have a long-term equilibrium relationship. Variables must be stationary for cointegration testing. Johansen's cointegration test will use the VAR (p) model. Next, the determination of the rank A expressed by $r$ through E-Views will be performed and then a Trace Test will be conducted to find the cointegration relationship.

Requirements to accept and reject VAR data tests:

$\mathrm{H}_{0}=$ probability $>5 \%$ (there is cointegration)

$\mathrm{H}_{1}=$ probability $<5 \%$ (there is no cointegration)

Error Correction Model (ECM) is a dynamic econometric model for determining cointegration equations in the short term, and ECM is used when there is a cointegration impact.

Requirements to accept and reject ECM data :

$\mathrm{H}_{0}=$ probability $>5 \%$ (Equation rejected)

$\mathrm{H}_{1}=$ probability $<5 \%$ (Equation accepted)

\section{Data analysis and discussion}

\subsection{Johansen's cointegration}

Table 1. Johansen's cointegration unrestricted cointegration rank test (Trace)

\begin{tabular}{|l|c|c|c|c|}
\hline Hypothesized & & Trace & 0.05 & \\
\hline No. of CE(s) & Eigenvalue & Statistic & Critical Value & Prob.** \\
\hline None * & 0.787160 & 170.4163 & 125.6154 & 0.0000 \\
\hline At most 1 * & 0.618906 & 114.7167 & 95.75366 & 0.0013 \\
\hline At most 2 & 0.569590 & 79.98717 & 69.81889 & 0.0062 \\
\hline At most 3 $*$ & 0.483435 & 49.63859 & 47.85613 & 0.0337 \\
\hline At most 4 & 0.329355 & 25.85864 & 29.79707 & 0.1330 \\
\hline At most 5 & 0.209110 & 11.47607 & 15.49471 & 0.1838 \\
\hline At most 6 & 0.080737 & 3.030597 & 3.841466 & 0.0817 \\
\hline
\end{tabular}

Trace test indicates 4 cointegrating eqn(s) at the 0.05 level

*denotes rejection of the hypothesis at the 0.05 level

**MacKinnon-Haug-Michelis $P$-values [25]

Based on the above Table 1, it can be seen that the trace statistic value and maximum eigenvalue at $r=0$ are greater than the critical value with a significance level of $5 \%$. This means that the null hypothesis, stating that there is no cointegration, is rejected and the alternative hypothesis stating that there is no cointegration cannot be rejected. Based on the econometric analysis above, it can be seen that among the variables in this study, there are four co-integrations at a significance level of $5 \%$. Thus, the results of the cointegration test indicate that the movement of GDP, inflation, exchange rate, debt to GDP ratio, infrastructure spending, lending rate, and FDI inflow have stability or balance impact and similarity of movements in the long run. In other words, in each short-term period, all variables tend to adjust to each other, to achieve their long-term equilibrium. 
Table 2. Normalized Cointegrating Normalized cointegrating coefficients

\begin{tabular}{|c|c|c|c|c|c|c|}
\hline FDI & GDP & INFLA & INFRA & KUR & RATIO & RATE \\
\hline 1.000000 & -0.457279 & 9.743625 & 1.568943 & -3.108533 & -1.277278 & 4.416341 \\
\hline & $(16.6072)$ & $(0.83467)$ & $(13.4400)$ & $(7.66914)$ & $(0.46956)$ & $(1.42121)$ \\
\hline
\end{tabular}

The Normalized and the Adjusted long run coefficients, as presented in the Table 2 were examined. However, attention is paid more in the normalized long run relationships due to the non-conformity of the signs of the coefficients to the expectation of the Adjusted coefficients.

GDP has a coefficient of -0.457279 , meaning that if the real interest rate increases by $1 \%$, then FDI will decrease by $0.457279 \%$. Inflation has a coefficient of 9.743625 , meaning that if inflation has increased $1 \%$ then FDI will rise by $9.743625 \%$. Infrastructure has a coefficient of 1.56894 , meaning that if infrastructure has increased 1 $\%$, then FDI will rise by $1.56894 \%$. The exchange rate has a coefficient of 3.108533 , meaning that if the exchange rate increases $1 \%$, then FDI will rise by $3.108533 \%$. The debt / GDP ratio has a coefficient of -1.277278 , meaning that if the debt / GDP ratio has increased by $1 \%$, then the FDI will decrease by $1.277278 \%$. The rate has a coefficient of 4.416341 , meaning that if the rate has increased $1 \%$, then FDI will rise by $4.416341 \%$.

\subsection{Estimate of error correction modeling (ECM)}

The cointegration of the variables as established with the Johansen's criterion above necessitates the ECM analysis based on the Engel-Granger Representation Theorem: if two or more variables are cointegrated, their impacts can be expressed in terms of Error Correction Modeling (ECM).

Table 3. Error Correction Modeling (ECM)

\begin{tabular}{lcccc}
\hline \multicolumn{1}{c}{ Variable } & Coefficient & Std. Error & t-Statistic & Prob. \\
\hline C & 0.684527 & 4.002675 & 0.171017 & 0.8654 \\
D(GDP) & 12.38102 & 29.12385 & 0.425116 & 0.6739 \\
D(INFLA) & 0.725764 & 0.245050 & 2.961698 & 0.0060 \\
D(INFRA) & 3.450049 & 6.593051 & 0.523286 & 0.6048 \\
D(KUR) & -19.50824 & 22.06677 & -0.884055 & 0.3839 \\
D(RASIOP) & -0.499873 & 0.218714 & -2.285511 & 0.0298 \\
D(RATE) & 1.578394 & 0.658047 & 2.398605 & 0.0231 \\
ECM(-1) & -1.271917 & 0.199009 & -6.391258 & 0.0000 \\
\hline R-squared & 0.711497 & Mean dependent var & 0.135721 \\
Adjusted R-squared & 0.641858 & S.D. dependent var & 10.99319 \\
S.E. of regression & 6.578867 & Akaike info criterion & 6.794413 \\
Sum squared resid & 1255.163 & Schwarz criterion & 7.142719 \\
Log likelihood & -117.6966 & Hannan-Quinn criter. & 6.917207 \\
F-statistic & 10.21698 & Durbin-Watson stat & 2.089301 \\
Prob(F-statistic) & 0.000002 & & & \\
\hline Dependent Variable: D(FDI) & & & \\
Method: Least Squares & & & \\
Date: 09/07/19 Time: 13:03 & & & \\
Sample (adjusted): 1982 2018 Included observations: 37 after adjustments & & \\
\hline
\end{tabular}

The coefficient of Disequilibrium Error Term (ECM) came up with the expected negative sign and is statistically significant considering its high t-statistics (-6.391 258), the result, therefore, is an indication that a short run impact exists between GDP, debt to GDP ratio, inflation, interest rate, exchange rates, and government infrastructure expenditure to FDI. 


\subsection{Analysis of variables}

If observed from the results between GDP and FDI, it shows that GDP has a significant long-term impact with a negative coefficient on FDI in Indonesia. This means that economic growth in Indonesia directly affects FDI in Indonesia. Economic growth having a significant impact with positive coefficients on investments made by foreign investors [15]. However, when viewed from GDP data in 1998 and 2015, FDI has tended to decline in those years. This is consistent with research conducted that GDP has a negative relationship with FDI [17].

The second variable is a debt to GDP, and the results show that the debt to GDP variable has a long-term impact with a negative coefficient on the value of FDI in Indonesia. This shows that the interest of foreign investors in investing their capital is influenced by Indonesia's debt to GDP ratio. This stating that the debt to GDP ratio has a negative influence on foreign investment [6]. The degree of the debt to GDP ratio of a country every year is one indicator of economic measurements regarding the level of the risk of destination countries for investment. Investors will see the debt to GDP ratio as a reference in investing. The greater the ratio of debt to GDP, the greater the debt of a country compared to state income. Foreign investors will see the value of the debt ratio as the value of risk in investing in Indonesia. In 1998, the debt to GDP ratio was $159 \%$ in Indonesia, which means that Indonesia's sovereign debt is $59 \%$ higher than income (GDP), causing foreign investors to hold their investment in Indonesia due to the large debt to GDP ratio. From 2003 onwards, Indonesia experienced an improvement in the debt to GDP ratio, where debt is smaller than $60 \%$ compared to the country's GDP. In accordance with regulations of Law Number 17 of 2003 concerning State Finances, the ratio of the country's debt is to a maximum of $60 \%$ compared to GDP. As a result of these improvements, FDI that occurred in Indonesia from 2003 to 2018 has increased every year and its peak in 2018, the highest in the history of Indonesia.

The third variable is inflation. The results show that the inflation variable has a significant positive impact on the value of FDI. This shows when inflation rises, FDI actually increases, and it applies vice versa. The inflation is positively related to FDI due to the occurrence of a stimulus in the economy, such as increased inflation and interest rates, so to provide a positive impact with FDI [6].

The fourth variable is the interest rate that uses the loan interest rate as a proxy. Regression results can show that interest rates have a long-term impact with a positive coefficient on FDI in Indonesia. This also shows that when Indonesian interest rates as a reference to IRP rise, it will increase the value of FDI in Indonesia. However, this research can be supported and can be explained by the IRP theory, which is a condition where the market will adjust the interest rate to the exchange rate so that there is no possibility of arbitrage so that a balanced state occurs. As a perspective, foreign investors will start investing when borrowing interest rates in their country (home country) are low compared to the host country. So foreign investors will invest in developing countries like Indonesia due to interest rates in the home country (home country) is smaller than the country (host country). This is consistent with the phenomenon that occurred when the US lowered its interest rate to near zero (0) in 2008 , Indonesia has adjusted to the increase in lending rates in 2009 from its original $13.60 \%$ to $14.50 \%$; and when America has raised its interest rates at the end of December 2015, Indonesia actually lowers the interest rates in early 2016.

The fifth variable is the USD exchange rate. The results show that the USD exchange rate variable has a significant negative impact on the amount of FDI. So, when the Rupiah is strengthening, FDI also increases. Investors will start investing when the Indonesian economy starts to improve. If we look at the fact of the exchange rate of Rupiah against the US dollar, in several years such as 1999, 2011 when the US dollar exchange rate strengthened, FDI also experienced a significant increase, but there were times in 2003, when the rupiah appreciated, FDI actually declined. This is consistent with research by 
Shetty et al.[25] who argues only at a certain level, and the exchange rate can affect FDI. This is appropriate considering that in 2002 and 2006, the USD exchange rate did not experience significant appreciation.

The last variable is infrastructure spending. The results can show that the infrastructure spending variable has a long-term impact with a positive coefficient on the value of FDI in Indonesia. Infrastructure spending undertaken by the Indonesian government can attract foreign investors to invest in Indonesia. In accordance with Anyanwu's [23] research, government spending can increase FDI, and in Musila and Sigue's [24] research on FDI show that FDI in Africa depends on the level of infrastructure development. Foreign investors will be more interested in countries that have infrastructure readiness and undertake infrastructure development; so as to cause of the increased investment in Indonesia, this is in line with the policy of infrastructure development undertaken by the administration of President Jokowi, in which the infrastructure budget is of three hundred trillion rupiahs in 2015 (the largest from the period 1981 to 2018).

\section{Conclusion}

Based on the results of the model studied, the following conclusions can be drawn: GDP, debt to GDP ratio, inflation, interest rates, exchange rates, and government infrastructure spending have long-term impacts on the FDI in Indonesia.

GDP, debt to GDP ratio, inflation, interest rates, exchange rates, and government infrastructure spending also have short-term impacts on FDI in Indonesia. Therefore, if the government of Indonesia wants to increase foreign investment in the form of FDI, it is important for the government to pay attention to macroeconomic indicators such as GDP, debt to GDP ratio, inflation, interest rates, and exchange rates to attract the attention of foreign investors. Infrastructure spending is also important in attracting investment.

\section{References}

1. H. Sasana, S. Fathoni, JEJAK Journal of Economics and Policy, 12,2:253-266(2019). https://doi.org/10.15294/jejak.v12i2.18785

2. D. Aditiasari, Jokowi Berani Hapus Subsidi BBM, Bikin Ekonomi RI Naik Pangkat. [Jokowi Dares to Remove Fuel Subsidies, Makes RI's Economy Rise]. [Online] from http://finance.detik.com/energi/d-2921902/jokowi-berani-hapus-subsidi-bbm-bikinekonomi-ri-naik-pangkat (2015). [in Bahasa Indonesia].

3. Sarwedi. Jurnal Akuntansi \& Keuangan, 4,1:17-35(2002). [in Bahasa Indonesia].. http://ced.petra.ac.id/index.php/aku/article/view/15688

4. M.K. Kenneth, International Journal of Economics, Commerce and Management, 5,11:386-399(2017). http://ijecm.co.uk/wp-content/uploads/2017/11/51122.pdf

5. A. M. Alshomali, Analysis of the Effect of Macroeconomic Factors on Foreign Direct Investment Inflowin Bahrain: The Ardl Bounds Testing Approach. [Research Paper].

Economies and Finance, Ahlia University (2019). p. 1-28. https://www.doi.org/10.13140/RG.2.2.21653.78563

6. E. Maghori, International Journal of Business and Social Science, 5,6:215-224(2014). https://pdfs.semanticscholar.org/dd70/0e723dc2eb6529f8b6de1c8091451557e112.pdf

7. E. Asiedu, World Development, 30,1:107-119(2004). https://onlinelibrary.wiley.com/doi/abs/10.1111/j.1467-8659.2004.00237.x

8. G. Haile, H. Assefa, Determinants of foreign direct investment in Ethiopia: A timeseries analysis. 4th International Conference on the Ethiopian Economy (Addis Ababa, Ethiopia, 2006), p. 168-198. 
https://westminsterresearch.westminster.ac.uk/item/9257q/determinants-of-foreigndirect-investment-in-ethiopia-a-time-series-analysis

9. M. Asiamah, D. Ofori, J. Afful, Journal of Asian Business and Economic Studies, 26,1:56-75(2019). https://doi.org/10.1108/JABES-08-2018-0057

10. V. Hemanona, Suharyono, Jurnal Administrasi Bisnis, 52,1:16-25(2017). [in Bahasa Indonesia]. https://media.neliti.com/media/publications/201956-analisis-pengaruhforeign-direct-investm.pdf

11. D. Fatihudin, M.A. Firmansyah, International Journal of Innovative Research \& Development, 7,11:67-71(2018).

http://internationaljournalcorner.com/index.php/ijird_ojs/article/view/139452

12. C. Utama, S.S. Agesy, Journal of Applied Ecomics, 6,2:155-175(2016). http://dx.doi.org/10.21776/ub.jiae.2016.006.02.2

13. S. Bosi, P. Fontaine, C.L. Van, Mathematical Social Sciences, 82:26-36(2016). https://doi.org/10.1016/j.mathsocsci.2016.04.002

14. C. Chin, Strategic Direction, 26,4:2727-2731(2010). https://doi.org/10.1108/sd.2010.05626dad.005

15. Z. Soumia, B. Abderrezzak, International Journal of Innovation and Applied Studies, 2,3:300-313(2013). https://pdfs.semanticscholar.org/5215/6f6ce1f981904e9afd754e7ecaf407105aad.pdf

16. A. Shahzad, A.K. Al-Swidi, Asian Social Science, 9,9271-279(2013). http://citeseerx.ist.psu.edu/viewdoc/download?doi=10.1.1.870.4141\&rep=rep1\&type= pdf

17. M.A. Mansaray, International Journal of Academic Research in Business and Social Sciences, 7,10:187-219(2017). http://hrmars.com/hrmars_papers/Macroeconomic Determinants_of Foreign_Direct Investment_Inflows and_Impulse_Response_Function.pdf

18. N. Marcu, S.-V. Carstina, S. Marian, Procedia Economics and Finance, 22:282286(2015). https://doi.org/10.1016/S2212-5671(15)00286-5

19. J. Ryan-Collins, R.A.Werner, J. Castle, International Fin. Markets, Inst. and Money 43:158-176(2016). https://doi.org/10.1016/j.intfin.2016.03.009

20. L. Ndikumana, M. Sarr, Resources Policy 63,1-13(2019), https://doi.org/10.1016/j.resourpol.2019.101432

21. S. Sukirno, Makroekonomi Teori Pengantar [Introduction to Theory of Macroeconomics], Jakarta: Rajawali Pers (2013). [in Bahasa Indonesia]. http://rajagrafindo.co.id/produk/makroekonomi-teori-pengantar-edisi-ketiga/

22. M.M. Rahman, E. Lau, Journal of International Business and Management 1,1:110(2018). http://rpajournals.com/wp-content/uploads/2018/07/JIBM-2018-01-46.pdf

23. J.C. Anyanwu, Determinants of Foreign Direct Investment Inflow to Africa, 19802007. Working Paper Series $\mathrm{N}^{\circ}$ 136, Tunis, Tunisia: African Development Bank (2011). https://core.ac.uk/download/pdf/6474811.pdf

24. W.J. Musila, S.P. Sique, Managerial Financial Journal, 32,7:577-593(2006). https://www.emeraldinsight.com/doi/abs/10.1108/03074350610671575

25. A. Shetty, J. Manley, N. Kyaw, Journal of Multinational Financial Management, 5253:100594(2019). https://doi.org/10.1016/j.mulfin.2019.100594\%20\%20 